\title{
The Problem of Wastewater in Shale Gas Exploitation The Influence of Fracturing Flowback Water on Activated Sludge at a Wastewater Treatment Plant
}

\author{
Maria Bartoszewicz ${ }^{2 *}$, Małgorzata Michalska², Monika Cieszyńska-Semenowicz', \\ Radosław Czernych ${ }^{1}$, Lidia Wolska ${ }^{1}$ \\ ${ }^{1}$ Medical University of Gdansk, Department of Environmental Toxicology \\ ${ }^{2}$ Medical University of Gdansk, Department of Immunobiology and Environmental Microbiology \\ Marii Skłodowskiej-Curie 3A, 80-210 Gdańsk, Poland
}

Received: 1 February 2016

Accepted: 12 April 2016

\begin{abstract}
Shale gas exploitation by hydraulic fracturing involves a number of environmental hazards, among which the neutralization and management of fracturing flowback waters is of particular importance. Chemical compounds present in the flowback water mainly constitute a threat to surface waters. The aim of our research was to determine the effects of these compounds on the state of activated sludge in a wastewater treatment plant employing biological treatment processes. Based on the obtained results, it was concluded that prior to the transfer of flowback water to a biological wastewater treatment system, it should be diluted with fresh water to lower the chloride ion concentration to the level of $1,000 \mathrm{mg} \mathrm{Cl} / \mathrm{dm}^{3}$. Although such a procedure would ensure the proper performance of a biological wastewater treatment system, it would not limit the migration of phthalates and thihalomethanes to surface waters.
\end{abstract}

Keywords: environment, activated sludge, shale gas, flowback waters

\section{Introduction}

The estimated resources of shale gas in Poland may be as high as $346 \times 10^{12} \mathrm{~m}^{3}$ [1] or even $5.3 \times 10^{18} \mathrm{~m}^{3}$ [2]. Shale gas occurs within ca. $12 \%\left(37,000 \mathrm{~km}^{2}\right)$ of Polish territory, with its deposits stretching from the northern boundary
(Pomorskie Voivodship) through Central Poland to the southeastern area of the country (Lubelskie Voivodship). The resources are so rich that Poland may become a future leader in the exploration of unconventional gas in Europe. In 2012 the Polish Ministry of the Environment granted 111 concessions to explore for shale gas. These were pursued by Polish (62 concessions) and foreign (49 concessions) companies [3].

*e-mail: grobela@iorpib.poznan.pl 
In order to exploit shale gas reserves from depths of ca. 2,000-3,000 m, the method of hydraulic fracturing is commonly used [4]. This method requires the use of drilling fluids (fracking fluids) whose chemical composition can vary quite widely. The drilling fluid contains inorganic compounds (mainly salts), organic compounds (mainly hydrocarbons), and such materials as bentonite and biopolymers, e.g. xanthan polymer $\mathrm{XCD}$ (a metabolite produced by Xantomonas campestris bacteria) and celulose- and starch-derived biopolymers [5]. Biopolymers used in drilling fluids undergo biodegradation mediated by, among others, aerobic and anaerobic amylolytic and celulose-digesting bacteria [6].

In the initial years of shale gas exploration, the exploring companies were repeatedly reassuring the public that hydraulic fracturing is safe for the environment. At present, it is known that this method is a source of many hazards to different environmental elements, mainly soil, surface water, groundwater, and air. The fact that fracking fluid can enter aquifers from which drinking water is extracted is particularly disturbing. In addition, the noise and vibrations associated with the fracking process are not neutral to human health [7].

Research results indicate that the chemical compounds present in fracking fluid are the main source of environmental contamination caused by hydraulic fracturing of shale gas reserves [5, 7-9]. More than 1,000 drilling fluids are available on the market, and ca. 630 chemical compounds are listed as their components. From among these chemicals, 353 are potentially hazardous to human health. Over $75 \%$ of the chemical compounds used in drilling fluids have a negative effect on the skin and eyes as well as the respiratory and digestive systems (via inhalation of aerosols). Ca. $40-50 \%$ of these chemicals can have an adverse impact on the nervous and immunological systems and kidneys, $37 \%$ on the hormonal system, and $25 \%$ can be carcinogenic and mutagenic agents. Many components of drilling fluids can also cause long-term health problems [7].

The used drilling fluid constitutes a waste, a so-called flowback water. Besides the initial components, the used fracking fluids also contain the products of reactions with rocks, plus gases and water originating from the exploited reserve. The longer the drilling fluid remains in the reserve, the more its chemical composition differs from the initial composition. Moreover, depending on the structure and origin of shale formations and geochemical characteristics of the reserve, the flowback water may also contain heavy metals and radioactive compounds whose negative effects on human health are commonly recognized [11-13]. Somewhat less knowledge is available about the influence of drilling fluids on the natural environment.

Based on the data disclosed by the explorers of Marcellus Shale (USA), the major components of flowback water are chlorine $\left(\mathrm{Cl}^{-}\right)$and sodium $\left(\mathrm{Na}^{+}\right)$ ions [2]. The flowback water can be reused as the basic component of fracking fluid or as an additive. However, prior to recycling, the flowback water has to be treated via flowback water cleaning systems. Rham et al. [4, 1213] demonstrated that in the case of low-salinity flowback water (on the order of ca. 12,000 $\mathrm{mg} \mathrm{Cl}^{-} / \mathrm{l}$ ) the treatment mainly consists of the removal of sediment, suspended matter, and hydrocarbon contaminants. When the salinity of flowback water is too high it has to be desalinated. To this end, electrodialysis, reverse osmosis, and thermal methods can be applied. Flowback water without prior desalination can be pumped into the depleted deposits or between the isolated absorbent layers in the deposit [12].

Moreover, measurements conducted during the exploitation of Marcellus Shale shale gas deposits indicate that a single drill hole requires the use of ca. $11,000-19,000 \mathrm{~m}^{3}$ of drilling fluid, which consists of $90.6 \%$ of water and $0.4 \%$ of added components such as the aforementioned polymers to increase viscosity, anticorrosion agents, surfactants, gelling agents, buffers, and others [5, 12-14]. It has been assumed that ca. 30-70\% of the total volume of fracturing fluid flows back to the surface. Based on the data published by the production companies, it is apparent that $0.6 \mathrm{~m}^{3}$ of drilling waste is produced per $1 \mathrm{~m}$ of distance drilled. Both the drilling fluid volume and flowback volume depend on the type of bedrock. Some deposits, described as "dry," require lower volumes of drilling fluid [5].

The transfer of flowback water to a municipal wastewater treatment plant is considered the simplest and most economical method of flowback water management. From the point of view of the Polish Act on waste (RP Journal of Laws, No. 62, item 628 dated 27 April 2001), the flowback water does not fulfill the criterion necessary for storing liquid waste, which includes wastes with a 95 wt. \% water content. Therefore, the flowback water has to be processed or managed in such a way as to avoid risk to the environment.

But flowback water may be a potential hazard to the functioning of activated sludge in the wastewater treatment plant and thus may pose a threat to the functioning of the plant. As a consequence, there is a possibility of introducing toxic waste into surface waters (receiving reservoir).

The aim of this paper is to assess the effect of substances present in the flowback water from hydraulic fracturing on activated sludge organisms. This is also the first article in a series of publications dedicated to a comprehensive discussion on the impact of technological processes used in shale gas exploitation on human health and the natural environment.

\section{Material and Methods}

\section{Fracturing Flowback Water}

The flowback water was pre-treated prior to sampling. The pre-treatment consists of filtering and coagulation in order to measure the content of total dissolved solids (TDS). 


\section{Activated Sludge}

The activated sludge used in this study had been obtained from a municipal wastewater treatment plant. The evaluation of activated sludge parameters was performed according to the procedures described by Eikelboom and Fijałkowska [15-16]. The qualitative species composition of activated sludge was assessed from microscopic observations (magnification 10x, 20x, and 40x) of slides treated with a vital stain.

The condition of sludge flocks (i.e., their shape, structure, size, and thread-like appearance) was evaluated from the microscopic observations (magnification 10x, 20x, and 40x) of slides treated with a vital stain.

The densities of Protozoa and Metazoa were estimated using a scale of 0 to 3 , and the density of filamentous bacteria in the activated sludge was estimated from microscopic observations (magnification 10x) of slides treated with a vital stain.

\section{Experimental Conditions}

The experiment was conducted at a micro-scale level. Four dilutions of flowback water were used, with chlorine ion concentrations of $200,500,750$, and $1,000 \mathrm{mg} \mathrm{Cl}^{-}$per $1,000 \mathrm{ml}$ of solution.

There were two variants of the experiment: the first variant in which the flowback fluid was diluted with mechanically treated raw sewage, and the second variant where the dilutions were made with tap water. The flowback water at the aforementioned concentrations was mixed with the activated sludge at a ratio of 1:2 in 1-liter flasks. The exposure time was $48 \mathrm{hr}$ at $20^{\circ} \mathrm{C}$. The samples of activated sludge and flowback water were continuously aerated during the duration of the experiment. A sample of activated sludge without the flowback water served as

Table 1. Taxonomic composition of organisms present in the analyzed activated sludge (dominant taxons).

\begin{tabular}{|c|c|}
\hline No. & Species name \\
\hline 1 & Arcella discoides \\
\hline 2 & Didinium nasutum \\
\hline 3 & Vorticella microstoma \\
\hline 4 & Vorticella $s p$. \\
\hline 5 & Epistilis lacustris \\
\hline 6 & Epistilis rotens \\
\hline 7 & Opercularia $s p$. \\
\hline 8 & Podophrya $s p$. \\
\hline 9 & Dicranophorus $s p$. \\
\hline 10 & Lecane $s p$. \\
\hline 11 & Cephalodella $s p$. \\
\hline 12 & Rotaria rotatora \\
\hline
\end{tabular}

a control. During the investigations, all samples and the control were supplied with raw sewage in order to deliver nutrients to living organisms.

After $48 \mathrm{hr}$, microscopic observations were conducted to evaluate the following parameters:

- The structure of active sludge flocks

- The presence of filamentous bacteria

- Species composition and vital functions of organisms living in the activated sludge

\section{Results}

The analyzed activated sludge was characterized by the mean number of filamentous bacteria (Index FI 3 on a five-point scale) ranging from five to 20 threads per flock. The domed amoebas (genus Arcellia), sedentary ciliates (genera Vorticella, Podophrya, Epistilis and Opercularia), free-swimming ciliates (genus Didinium), and rotifers (genera Rotatoria, Cephalodella, Lecane, Dicranophorus) were found in the sludge. The taxonomic composition of Protozoa and Metazoa indicated stable conditions and good performance of the sludge (Table 1).

The flocks present in the analyzed activated sludge were irregular in shape and their structure was compact, while flock size and the presence of filaments was at the medium level. The density of organisms belonging to Protozoa and Metazoa was estimated based on a scale from 0 to 3 (Table 2).

\section{Impact Assessment of Chemical Compounds Present in the Flowback Water on the State of Activated Sludge}

The initial chloride concentration in the sample of flowback water was $58,000 \mathrm{mg} \mathrm{Cl} / \mathrm{dm}^{3}$. In this study, four dilutions of flowback water were used, i.e., 200, 500,750 , and $1,000 \mathrm{mgCl}^{-} / \mathrm{dm}^{3}$. After a $48-\mathrm{hr}$ exposure of activated sludge to the flowback water, the selected

Table 2. The densities of organisms belonging to Protozoa and Metazoa (on a scale of 0 to 3 ).

\begin{tabular}{|l|c|}
\hline Protozoans and invertebrates, including: & Scale (0-3) \\
\hline Protozoa: & \\
naked amoebas & 0 \\
domed amoebas & 3 \\
radiolarians & 0 \\
flagellates & 1 \\
\hline sedentary ciliates & 2 \\
crawling ciliates & 0 \\
free-swimming ciliates & 2 \\
\hline Metazoa: & 2 \\
rotifers & 0 \\
nematodes & 0 \\
oligochaetes & 0 \\
tardigrades & 0 \\
copepods & \\
\hline
\end{tabular}


Table 3. Assessment of activated sludge after 48-hr exposure to flowback water at different concentrations (flowback water was diluted with tap water).

\begin{tabular}{|c|c|c|c|c|}
\hline Dilution & $200 \mathrm{mg} / \mathrm{dm}^{3}$ & $500 \mathrm{mg} / \mathrm{dm}^{3}$ & $750 \mathrm{mg} / \mathrm{dm}^{3}$ & $1,000 \mathrm{mg} / \mathrm{dm}^{3}$ \\
\hline $\begin{array}{l}\text { Flock evaluation: } \\
\qquad \begin{array}{c}\text { shape } \\
\text { structure } \\
\text { size } \\
\text { presence of filaments }\end{array} \\
\end{array}$ & $\begin{array}{l}\text { irregular } \\
\text { compact } \\
\text { medium } \\
\text { medium }\end{array}$ & $\begin{array}{l}\text { irregular } \\
\text { compact } \\
\text { medium } \\
\text { medium }\end{array}$ & $\begin{array}{l}\text { irregular } \\
\text { compact } \\
\text { medium } \\
\text { medium }\end{array}$ & $\begin{array}{l}\text { irregular } \\
\text { compact } \\
\text { medium } \\
\text { medium }\end{array}$ \\
\hline $\begin{array}{l}\text { Presence of filamentous bacteria (Index of } \\
\text { filamentous bacteria) }\end{array}$ & FI 3 (medium) & FI 3 (medium) & FI 3 (medium) & FI 3 (medium) \\
\hline $\begin{array}{l}\text { Protozoa: } \\
\qquad \text { naked amoebas } \\
\text { domed amoebas } \\
\text { radiolarians } \\
\text { flagellates }\end{array}$ & $\begin{array}{l}0 \\
3 \\
0 \\
2\end{array}$ & $\begin{array}{l}0 \\
3 \\
0 \\
1\end{array}$ & $\begin{array}{l}0 \\
3 \\
0 \\
2\end{array}$ & $\begin{array}{l}0 \\
3 \\
0 \\
2\end{array}$ \\
\hline $\begin{array}{l}\text { sedentary ciliates } \\
\text { crawling ciliates } \\
\text { free-swimming ciliates }\end{array}$ & $\begin{array}{l}2 \\
0 \\
2\end{array}$ & $\begin{array}{l}2 \\
0 \\
2\end{array}$ & $\begin{array}{l}2 \\
0 \\
2\end{array}$ & $\begin{array}{l}1 \\
0 \\
2\end{array}$ \\
\hline $\begin{array}{l}\text { rotifers } \\
\text { nematodes } \\
\text { oligochaetes } \\
\text { tardigrades } \\
\text { copepods }\end{array}$ & $\begin{array}{l}2 \\
0 \\
0 \\
0 \\
0\end{array}$ & $\begin{array}{l}2 \\
0 \\
0 \\
0 \\
0\end{array}$ & $\begin{array}{l}2 \\
0 \\
0 \\
0 \\
0\end{array}$ & $\begin{array}{l}2 \\
0 \\
0 \\
0 \\
0\end{array}$ \\
\hline
\end{tabular}

sludge parameters were compared to those of the initial sample and the control. The obtained results are presented in Tables 3 and 4.

It was observed that after a 48-hr exposure to the flowback water at the chloride ion concentrations equal to or lower than 1,000 mg (Table 3), the activated sludge did not display any significant changes with regard to its vital functions and species composition.
However, the density of sedentary ciliates (on a scale of 0 to 3 ) relative to the control decreased from 2 to 1 for the chloride ion concentration of $1,000 \mathrm{mgCl}^{-} / \mathrm{dm}^{3}$.

Flock parameters such as compactness, shape, the presence of filaments, and flock size did not change. The index of filamentous bacteria also did not change, assuming an FI value of 3, which expresses the mean number of filamentous bacteria in the activated sludge (Table 3 ).

Table 4. Assessment of activated sludge after 48-hr exposure to flowback water at specified concentrations (the original flowback water was diluted with mechanically treated raw sewage).

\begin{tabular}{|c|c|c|c|c|}
\hline Dilution & $200 \mathrm{mg} / \mathrm{dm}^{3}$ & $500 \mathrm{mg} / \mathrm{dm}^{3}$ & $750 \mathrm{mg} / \mathrm{dm}^{3}$ & $1,000 \mathrm{mg} / \mathrm{dm}^{3}$ \\
\hline $\begin{array}{c}\text { Flock evaluation: } \\
\qquad \begin{array}{c}\text { shape } \\
\text { structure } \\
\text { size } \\
\text { presence of filaments }\end{array}\end{array}$ & $\begin{array}{l}\text { irregular } \\
\text { compact } \\
\text { medium } \\
\text { medium }\end{array}$ & $\begin{array}{l}\text { irregular } \\
\text { compact } \\
\text { medium } \\
\text { medium }\end{array}$ & $\begin{array}{l}\text { irregular } \\
\text { compact } \\
\text { medium } \\
\text { medium }\end{array}$ & $\begin{array}{l}\text { irregular } \\
\text { compact } \\
\text { medium } \\
\text { medium }\end{array}$ \\
\hline Presence of filamentous bacteria & FI 3 (medium) & FI 3 (medium) & FI 3 (medium) & FI 3 (medium) \\
\hline $\begin{array}{l}\text { naked amoebas } \\
\text { domed amoebas } \\
\text { radiolarians } \\
\text { flagellates }\end{array}$ & $\begin{array}{l}0 \\
3 \\
0 \\
2\end{array}$ & $\begin{array}{l}0 \\
3 \\
0 \\
2\end{array}$ & $\begin{array}{l}0 \\
3 \\
0 \\
2\end{array}$ & $\begin{array}{l}0 \\
3 \\
0 \\
2\end{array}$ \\
\hline $\begin{array}{c}\text { sedentary ciliates } \\
\text { crawling ciliates } \\
\text { free-swimming ciliates }\end{array}$ & $\begin{array}{l}2 \\
0 \\
2\end{array}$ & $\begin{array}{l}1 \\
0 \\
2\end{array}$ & $\begin{array}{l}1 \\
0 \\
2\end{array}$ & $\begin{array}{l}1 \\
0 \\
2\end{array}$ \\
\hline $\begin{array}{l}\text { rotifers } \\
\text { nematodes } \\
\text { oligochaetes } \\
\text { tardigrades } \\
\text { copepods }\end{array}$ & $\begin{array}{l}2 \\
0 \\
0 \\
0 \\
0\end{array}$ & $\begin{array}{l}2 \\
0 \\
0 \\
0 \\
0\end{array}$ & $\begin{array}{l}2 \\
0 \\
0 \\
0 \\
0\end{array}$ & $\begin{array}{l}2 \\
0 \\
0 \\
0 \\
0\end{array}$ \\
\hline
\end{tabular}


When the activated sludge was exposed to the flowback water diluted with mechanically treated raw sewage, no significant changes in the species composition and the state of the sludge were observed. Flock parameters such as compactness, shape, the presence of filaments, and flock size did not change. The index of filamentous bacteria remained stable, reaching the value of FI-3, which expresses the mean number of filamentous bacteria in the activated sludge (Table 4).

The substances and chemical compounds present in the flowback water diluted with raw sewage had a stronger effect on the density of sedentary ciliates (Protozoa) compared to the flowback water diluted with tap water. The density of sedentary ciliates (on a scale of 0 to 3 ) relative to the control decreased from 2 to 1 for the chloride concentrations of 500, 750, and 1,000 $\mathrm{mgCl}^{-} / \mathrm{dm}^{3}$ (Table 4). The density and vital activities of Metazoa in the activated sludge did not change for two different dilutants used, i.e., tap water and raw sewage.

\section{Discussion}

Gas extraction by hydraulic fracturing requires the use of huge amounts of water, namely on the order of $20 \times 10^{6}$ per drill hole. Ca. $70 \%$ of this volume returns to the surface in the form of waste - so-called flowback water. The management of flowback water poses a big challenge for the mining industry [13-14].

The transfer of flowback water to a municipal wastewater treatment plant is one of the many possible solutions in flowback water management. It seems to be the simplest method for flowback water disposal with regard to technological and economic aspects. The application of reverse osmosis is also possible, but it is more costly.

Irrespective of the treatment method used, municipal wastewater treatment plants are unsuited for the removal of contaminants from fluids characterized by chemical composition similar to that of fracturing flowback water. The substances contained in flowback water can disturb the processes involved in wastewater treatment, particularly biological processes [17].

The results of this study demonstrate that the chemical compounds present in the flowback water, particularly the chloride ion concentrations equal to or lower than $1,000 \mathrm{mg} \mathrm{Cl}-/ \mathrm{dm}^{3}$, did not affect flock parameters, i.e., compactness, shape, the presence of filaments, and flock size of the activated sludge. The index of filamentous bacteria also remained stable, reaching the value of FI-3, which expresses the mean number of filamentous bacteria in the activated sludge (Tables 3 and 4).

Although no changes were observed in the species composition of the activated sludge after exposure to the flowback water, in some cases the density of sedentary ciliates - an important component of activated sludge decreased.

In the case of flowback water diluted with mechanically treated raw sewage, the number of sedentary ciliates (on a scale of 0 to 3 ) relative to the control decreased from 2 to 1 for the chloride ion concentrations of 500, 750, and $1,000 \mathrm{mg} \mathrm{Cl}-/ \mathrm{dm}^{3}$. For the flowback water diluted with tap water, the density of sedentary ciliates decreased from 2 to 1 only at the chloride ion concentration equal to $1,000 \mathrm{mg} \mathrm{Cl} / \mathrm{dm}^{3}$ (Table 3). It can be assumed that a decrease in the density of sedentary ciliates in the activated sludge resulted from the cumulative impact of the substances present in the flowback water and raw sewage.

Because the chemical composition of commercially available drilling fluids widely vary, the flowback waters are also characterized by diverse composition. Moreover, the chemical properties of flowback waters change depending on deposit type, the chemical composition of groundwater, and on how long the drilling fluid remains in the deposit. The transfer of flowback water to a municipal wastewater treatment plant employing biological treatment processes would require initial desalination and dilution of the original flowback water to attain a concentration that could not affect the quality of activated sludge.

The results obtained in our study indicate that a chloride ion concentration in flowback water of ca. $1,000 \mathrm{mg} \mathrm{Cl}^{-} / \mathrm{dm}^{3}$ is safe for activated sludge.

The effect of chemical compounds present in the flowback waters on living organisms in the activated sludge has not been fully elucidated. It is only known that these compounds are not biodegradable, or that their biodegradation is very slow $[14,18]$. Because of that, the transfer of flowback waters to municipal wastewater treatment plants is not a risk-free solution for managing this particular waste.

Lowering the chloride concentration in the flowback waters would not disturb biological treatment processes. However, it should be kept in mind that municipal wastewater treatment plants have not been designed to remove other chemical substances present in the flowback water. Thus such substances would only get diluted prior to their disposal into surface waters.

It seems that a particular threat is related to the formation of trihalomethanes due to the reaction between bromides (in the flowback water) and chlorine compounds used for disinfecting wastewater at municipal wastewater treatment plants. High doses of trihalomethanes have demonstrated carcinogenic activity in laboratory animals [10, 19-20].

Trihalomethanes may enter surface waters via the disposal of treated wastewater, thus becoming a potential risk to human health if these waters are used for drinking [21]. The risk of developing cancer is not the only hazard associated with the presence of trihalomethanes in water. Trihalomethanes are classified as diabetogenic substances. The most recent research results indicate that exposure to trihalomethanes has an effect on the development of type II diabetes. This is particularly visible in obese persons who are exposed to large doses of trihalomethanes [2224].

Phthalanes, chemical compounds displaying endocrine activity in humans and animals, are another component 
of drilling fluids, including: dibutyl phthalate, diethyl phthalate, dioctyl phthalate, and butyl benzyl phthalate. The presence of the aforementioned compounds in surface waters, which can potentially be used for drinking water extraction, may result in hormonal imbalance in humans. This has been confirmed by scientific studies dating back to the 1990s [2, 23, 25-32].

Animal studies (research conducted on human subjects is rare) suggest that phthalates are a cause of decreased birth rates, preterm births, and low birth weight, as well as lowered fertility and altered genital development in males. Moreover, phthalates are bioaccumulated in the food chain [33].

The exploitation of shale gas in Poland creates hope for gaining access to relatively inexpensive and - most importantly - domestically sourced energy. This could possibly result in the reduced volume of imported gas and more self-sufficiency in energy production. However, technological processes used in shale gas production are a large burden on the environment. This fact has to be considered when the costs of shale gas exploitation are estimated.

The management of huge amounts of fracturing flowback water is one problem that has to be solved in order to reduce the negative impact on the environment. Unfortunately, a single efficient technology for flowback water recycling has not yet been developed [11]. On the other hand, the idea of transferring flowback waters to municipal wastewater treatment plants seems to be controversial because of its economic aspects, i.e., the significant costs of storage, desalination, and dilution of these waters.

Based on the experiments conducted in this study, it can be stated that prior to its transfer to a municipal wastewater treatment plant employing biological treatment, the flowback water should be diluted with fresh water to lower the chloride ion concentration to the level of $1,000 \mathrm{mg} \mathrm{Cl} / \mathrm{dm}^{3}$. The flowback water cannot be directly dispensed into the activated sludge system (reactor tanks in which biological treatment takes place). Although the dilution step would ensure the proper activity of biological wastewater treatment, it would not reduce the migration pathway of phthalates and trihalomethanes in surface waters. This is one of the reasons why the transfer of flowback waters to wastewater treatment plants is forbidden in many U.S. states [34].

\section{Conclusions}

In the opinion of the authors, the presented work is one of few studies aimed at finding solutions to the problems associated with shale gas exploitation in Poland. A comprehensive impact assessment of hydraulic fracturing on the state of the natural environment will only be possible based on the results of continuous monitoring of flowback waters with regard to their chemical, microbiological, and toxicological parameters.

\section{References}

1. Polish Geological Institute National Research Institute. Assesment of shale gas and shale oil resources of the lower Paleozoic Baltic - podlasie-lublin basin in Poland first report, www.pgi.gov.pl, 2012.

2. STATES S., CASSON L., CYPRYCH G., MONNELL J., STONER M., WYDRA F. Bromide in the Allegheny river and THMs in Pittsburgh drinking water: a link with Marcellus shale drilling, American Water Works Association - Water Quality Technology Conference, Phoenix Arizona, November 13-17 2011. On line: http://www. essentialpublicradio.org/sites/default/files/story/extras/, 28.09.2015.

3. Ministry of the Environment of the Republic of Poland maps of concession, www.mos.gov.pl.

4. RHAM D. Regulating hydraulic fracturing in shale gas plays: The case of Texas. Energ Policy. 39 (5), 2974, 2011.

5. HAMMER R. In Fracking's Wake: New Rules are Needed to Protect Our Health and Environment from Contaminated Wastewater, Natural Resources Defense Council, 2012, http://www.nrdc.org/energy/files/Fracking-WastewaterFullReport.pdf 28.09.2015.

6. Ecotoxicology Division Assessing the Environmental Performance of Drilling Fluids, Geotechnical Services PTY LDT, www.geotechnical-services.com.au/Ecotox - Drilling Fluids 2012 05.pdf, 28.09.2015.

7. VENGOSH A., JACKSON R.B., WARNER N., DARRAH T.H., KONDASH A. A critical Review of the Risks to water resources form Unconventional shale gas development and hydraulic fracturing in the United States. Environ Sci Technol. 48, 8334, 2014.

8. OLMSTEAD S.M., MUEHLENBACHS L.A., SHIH J.S., CHU Z., KRUPNICK A.J. Shale gas development impacts on surface water quality in Pennsylvania. Proc Natl Acad Sci USA. 110 (13), 4962, 2013.

9. Technically Recoverable Shale Oil and Shale Gas Resources: An Assessment of 137 Shale Formations in 41 Countries Outside the United States, 2013, U.S. Energy Information Administration, on line.

10. WANG G.S., DENG Y.C., LIN T.F. Cancer risk assessment from trihalomethanes in drinking water. Sci Total Environ. 15, 387 (1-3), 86, 2007.

11. HOWARTH R.W., INGRAFFEA A., ENGELDER T. Natural gas: Should fracking stop? Nature, 477, 271, 2011 http://www.nature.com/natu22re/journal/v477/n7364/ full/477271a.html, 28.09.2015.

12. RAHM B.G., RIHA S.J. Evolving shale gas management: water resource risks, impacts and lessons learned. Environ Sci. Processes Impacts. 16, 1400, 2014.

13. RAHM B.G., BATES J.T., BERTOIA L.R., GALFORD A.E., YOXTHEIMER D.A., RIHA S.J. Wastewater management and Marcellus Shale gas development: Trends, drivers, and planning implications. J Environ Manage. 120, 105, 2013.

14. NAIR L.S., LAURENCIN C.T. Biodegradable polymers as biomaterials. Progress in Polymer Science. 32 (8-9), 762, 2007.

15. EIKELBOOM D.H. Process Control of Activated Sludge Plants by Microscopic Investigation. IMA Publishing. 1, 2014.

16. FIJAŁKOWSKA E. Osad czynny biologia i analiza mikroskopowa (Activated sludge biology and microscopy analysis), $1^{\text {rd }}$ ed. Oficyna Wydawnicza IMPULS, Poland, Kraków, 1, 2005. 
17. NICOT J.P., SCANLON B.R. Water use for shale gas production in Texas, U.S. Environ Sci Technol. 46 (6), 3580, 2012.

18. 1SHAH A.A., HASAN F., HAMEED A., AHMED S. Biological degradation of plastics: A comprehensive review. Biotechnology Advances. 26, 246, 2008.

19. FERRAR K.J., MICHANOWICZ D.R., CHRISTEN C.L., MULCAHY N., MALONE S.L., SHARMA R.K. Assessment of Effluent Contaminants from Three Facilities Discharging Marcellus Shale Wastewater to Surface Waters in Pennsylvania. Environ. Sci. Technol. 47 (7), 3472, 2013.

20. HARKNESS J.S., DWYER G.S., WARNER N.R., PARKER K.M., MITCH W.A., VENGOSH A. Iodide, bromide, and ammonium in hydraulic fracturing and oil and gas wastewaters: environmental implications. Environ Sci Technol. Feb 113, 49 (3), 1955, 2015.

21. JACKSONR.B., VENGOSHA., DARRAH T.H., WARNER N.R., DOWN A., POREDA R.J., OSBORN S.G., KARR J.D. Increased stray gas abundance in a subset of drinking water wells near Marcellus shale gas extraction. Proc Natl Acad Sci USA. Volume 110 (28), 11250, 2013.

22. ANDRA S.S., CHARISIADIS P., MAKRIS K.C. Obesitymediated association between exposure brominated trihalmethanes and type II diabetes mellitus: An exploratory analysis. Sci. Total. Environ. 485-486, 340, 2014.

23. LINA S., HSIU-YING K. PEN-HUA S., JEIN-WEN C., POCHIN H., ANGERERE J., SHU-LI W. Phthalate exposure in pregnant women and their children in central Taiwan. Chemosphere. 82 (7), 947, 2011.

24. PARKER K.M., ZENG T., HARKNESS J., VENGOSH A., MITCH W.A. Enhanced formation of disinfection byproducts in shale gas wastewater-impacted drinking water supplies. Environ Sci Technol. 48 (19), 11161, 2014.

25. BÖSE-O'REILLY S., HEUDORF U., LOB-CORZILIUS T., MÜHLENDAHL K. E., OTTO M., SCHMIDT S. Children's environment in Central Europe: Threats and chances, Results of an International Workshop held on November 21-24, 2006 in Osnabrück. Int. J. Hyg. Envir. Heal. 210 (5), 623, 2007.
26. FAWELL J.K., SHEAHAN D., JAMES H. A., HURST M., SCOTT S. Oestrogens and Oestrogenic Activity in Raw and Treated Water in Severn Trent Water. Water Res. 35 (5), 1240, 2001.

27. HARRIES J.E, SHEAHAN D.A, JOBLING S., MATTHIESSEN P., NEALL P., SUMPTER J.P., TYLOR T., ZAMAN N. Estrogenic activity in five United Kingdom rivers detected by measurement of vitellogene 15 sis in caged male trout. Environ. Toxicol. Chem. 16, (3), 534, 1997.

28. HEUDORFA U., MERSCH-SUNDERMANNB V., ANGERER J. Phthalates: Toxicology and exposure. Int. J. Hyg. Envir. Heal. 210, 623, 2007.

29. HYUN J.K., BYUNG M.L. Human monitoring of Phthalates and risk Assessment. J Toxicol Env Health A. 70 (15-16), 1379, 2007

30. HYUN J.K., BYUNG M.L. Hershberger Assay for Antiandrogenic Effects of Phthalates. J Toxicol Env Health A, Current Issues Special Issue Current Toxicological Issues in Korea. 70 (15-16), 136530, 2007.

31. MATSUMOTO M., HIRATA-KOIZUMI M., EMA M. Potential adverse effects of phthalic acid esters on human health: A review of recent studies on reproduction. Regul Toxicol Pharmacol. 50 (1), 37, 2008.

32. STAPLES C. A, GUINN R., KRAMARZ K., LAMPI M. Assessing the Chronic Aquatic Toxicity of Phthalate Ester Plasticizers. Hum Ecol Risk Assess. 17 (5), 1057, 2011.

33. FROMME H., ALBRECHT M., ANGERER J., DREXLER H., GRUBER L., SCHLUMMER M., PARLAR H., KÖRNER W., WANNER A., HEITMANN D., ROSCHER E., BOLTE G. Integrated Exposure Assessment Survey (INES): Exposure to persistent and bioaccumulative chemicals in Bavaria, Germany. Int. J. Hyg. Envir. Heal. 210 (3-4), 345, 2007.

34. WILSON J.M., VAN BRIESEN J.M. Source water changes and energy extraction activities in the Monongahela River, 2009-2012. Environ Sci Technol. 47 (21), 12575, 2013. 